\title{
OPTIMALISASI PERAN DEWAN PENGAWAS SYARIAH (DPS) \\ DALAM MENJAGA KEPATUHAN SYARIAH \\ PADA PERBANKAN SYARIAH DI INDONESIA
}

\author{
Sumar'in Asmawi, \\ Sultan Muhammad Syafiuddin Institute of Islamic Studies of Sambas \\ Kalimantan Barat
}

\begin{abstract}
The challenge of financial globalization impact on Islamic finance businesses to maintain shariah compliance aspects as a means of mistake prevention and possible risks in the real sector. Compliance functions as actions and measures, both are preventive to ensure the policies, rules, systems and procedures, the business activities carried out by the Islamic Bank. The design of this study is library reaserch approach. The result shows that the system of supervision of compliance toward sharia must been done based on the rules by DPS. The functions of DPS on Islamic Banking, normatively must been implemented in accordance with the principles of compliance, the compliance culture, management risk and the values of shariah systems. The existence of DPS really determines the establishment of sharia compliance, which becomes the main unsure in the existence and continuity of syariah financial industry.
\end{abstract}

Keyword: shariah systems, shariah compliance and DPS.

\section{A. Pendahuluan}

Persaingan dunia perbankan pada era globalisasi saat ini semakin ketat akibat semakin majunya usaha perbankan baik dalam maupun luar negeri, sehingga setiap usaha perbankan berusaha memanfaatkan seoptimal mungkin dalam penggunaan dana dan teknologi yang dimilikinya. Merujuk pada 
Undang-Undang Nomor 21 Tahun 2008 tentang perbankan, menjelaskan bahwa Bank adalah badan usaha yang menghimpun dana dari masyarakat dalam bentuk simpanan dan menyalurkannya kepada masyarakat dalam bentuk pembiayaan dan atau bentuk-bentuk lain dalam rangka meningkatkan taraf hidup rakyat banyak. ${ }^{1}$ Perbankan merupakan lembaga yang berfungsi sebagai intermediasi yang menyimpan dana dari pihak yang kelebihan dana dan menyalurkan dana kepada pihak yang kekurangan dana.

Perbankan syari'ah merupakan sebuah sistem yang menghilangkan sistem bunga dalam setiap transaksi keuangan yang dilakukannya dan diganti dengan prinsip-prinsip syariah. Eksistensi perbankan syari'ah itu sendiri, diawali dengan terbentuknya PT.Bank Muamalat Indonesia pada tahun 1991. Konsep ekonomi syari'ah diyakini menjadi sistem imun yang efektif bagi Bank Muamalat Indonesia sehingga tidak terpengaruh oleh gejolak krisis ekonomi. Dalam perkembangannya, bank syariah menjadi sebuah model bisnis baru yang menarik banyak pihak termasuk didalamnya pihak perbankan konvensional yang ikut mendirikan dan mengubah sistem perbankan mereka dangan bank sistem syari'ah.

Seiring dengan berjalannya waktu perbankan syari'ah di Indonesia mengalami kemajuan yang cukup pesat dari tahun ke tahun. Menurut data Statistik OJK per 30 September 2016 tercatat total aset bank syariah telah mencapai Rp 331,76 triliun atau tumbuh sebesar 17,58\% pertahun. Pertumbuhan ini ditopang oleh penghimpunan dana Pihak ketiga (DPK) sebesar Rp 263,52 triliun atau tumbuh 20,16\% pertahun. Dan pangsa pasar aset perbankan syariah terhadap perbankan nasional sudah mencapai 5,31\%.2

Melihat data diatas memberikan gambaran bahwa perkembangan perbankan syariah di Indonesia sangat meyakinkan. Namun, seiring perkembangannya itu masih banyak masalah yang harus dihadapi oleh

${ }^{1}$ Undang-Undang Nomor 21 Tahun 2008 tentang Perbankan Syariah pasal 1 dan 2.

${ }^{2}$ Lihat data OJK per Oktober 2016. 
lembaga perbankan syariah tersebut. Tingginya perkembangan perbankan Syariah di Indonesia ternyata tidak diikuti dengan sistem pengawasan dan penerapan syariah yang ketat oleh lembaga pengawas. Padahal aspek kepatuhan syariah adalah inti dan pembeda antara bank Islam dan bank Konvensional.

Kepatuhan syariah (shariah compliance) adalah hal utama yang menjadi pembeda antara ekonomi syariah dengan ekonomi konvensional atau antara perbankan syariah dengan perbankan konvensional. ${ }^{3}$ Penerapan prinsipprinsip syariah menjadi suatu keharusan bagi sebuah institusi syariah, termasuk di dalamnya institusi bank syariah. Hal ini lebih ditujukan sebagai bentuk tanggung jawab pada publik (public accountability) berkaitan dengan kegiatan operasional bank yang diharapkan benar-benar mematuhi ketentuanketentuan yang telah digariskan dalam hukum syariah. Menjadi hilang ruh dan nilai syariahnya ketika perbankan syariah hanya mengejar keuntungan tanpa melihat dan menjaga aspek syariah dari core bisnis bank. Karena pada prinsipnya, masyarakat sangat percaya dan memberikan stigma positif terhadap hadirnya bank syariah sebagai bank yang halal dan berkah.

Lebih lanjut menurut Setiawan, dalam penerapan sistem operasional perbankan syariah, masih tampak dibatasi oleh distorsi dalam ekonomi, seperti kurangnya kerangka pengawasan yang kuat dan regulasi yang cermat dalam sistem keuangan. ${ }^{4}$ Artinya merujuk pada pendapat Setiawan, penerapan kepatuhan syariah masih menjadi distorsi dalam beberapa konteks aplikasi di bank syariah. Chapra menjelaskan, perbankan Islam sebagai salah satu lembaga intermediasi belum mampu melakukan perubahan pada tatanan sosial utamanya untuk saling mengenal, adanya peran kekeluargaan, suku serta ikatan sufistik religius yang dapat memberikan kepercayaan dan menjaga

\footnotetext{
${ }^{3}$ M. Syafi'i Antonio, Bank Syariah dari Teori ke Praktik, (Jakarta : Penerbit Gema Insani, 2001), hlm. 125

${ }^{4}$ Aziz Budi Setiawan, "Perbankan Syariah; Challenges dan Opportunity Untuk Pengembangan di Indonesia", Jurnal Kordinat, Edisi: Vol.VIII No.1, April 2006, hlm. 1-13.
} 
hubungan stakeholders. ${ }^{5}$ Hal ini tentunya menjadikan peran bank syariah sebagai lembaga keuangan yang dianggap berperan ganda baik sebagai shahibul maal maupun mudharib belum dijalankan seutuhnya, utamanya dalam memberikan pembinaan dan pendidikan pada masyarakat.

Pihak Bank Indonesia selaku pemegang regulasi perbankan syariah di Indonesia sendiri berusaha untuk mendorong praktik perbankan syariah yang kuat dan sehat secara finansial dan senantiasa mengacu kepada prinsipprinsip syariah, maka bank syariah diharapkan dapat melaksanakan prinsipprinsip GCG berupa transparansi, akuntabilitas, tanggung jawab, kebebasan dan kewajaran dan kepatuhan kepada ketentuan-ketentuan syariah (shariah compliance).

Menurut Zainal, Kepatuhan syariah dalam bank syariah adalah penerapan prinsip-prinsip Islam, syariah dan tradisinya dalam transaksi keuangan dan perbankan serta bisnis lain yang terkait. ${ }^{6}$ Artinya kepatuhan syariah adalah komitmen bank untuk menjalakan prinsip-prinsip syariah dalam setiap operasional yang dijalankan. Lebih lanjut menurut Adrian Sutedi, kepatuhan syariah dalam operasional bank syariah tidak hanya meliputi produk saja, akan tetapi meliputi sistem, teknik dan identitas perusahaan. Karena itu, budaya perusahaan yang meliputi pakaian, dekorasi dan image perusahaan merupakan salah satu aspek kepatuhan syariah dalam bank syariah. Tujuannya, tidak lain untuk menciptakan suatu moralitas dan spiritual kolektif, yang apabila digabungkan dengan produksi barang dan jasa, maka akan menopang kemajuan dan pertumbuhan jalan hidup yang islami. ${ }^{7}$

Oleh karena itu, sangat penting untuk dilakukan terkait pengawasan fungsi kepatuhan syariah di industri keuangan syariah, dimana fungsi

${ }^{5}$ M. Umer Chapra dan Habib Ahmed, Corporate Governance Lembaga Keuangan Syariah, diterj. Oleh Ikhwan Abidin Basri, (Jakarta: Bumi Aksara, 2008), hlm. 11 hlm. 2 .

${ }^{6}$ Zainal Arifin, Dasar-dasar Manajemen Bank Syariah, (Tangerang: Aztera Publisher, 2009),

${ }^{7}$ Adrian Sutedi, Perbakan Syariah, Tinjauan dan Beberapa Segi Hukum (Jakarta: Ghalia Indonesia, 2009), hlm. 145. 
kepatuhan merupakan tindakan dan langkah yang bersifat ex-ante (preventif), untuk memastikan kebijakan, ketentuan, sistem dan prosedur, serta kegiatan usaha yang dilakukan oleh Bank Islam sesuai dengan ketentuan Bank Indonesia, fatwa DSN dan peraturan perundang-undangan yang berlaku. ${ }^{8} \mathrm{Hal}$ ini dilakukan untuk mengontrol operasional perbankan syariah serta menjadikan bank syariah agar tidak keluar dari koridornya, disiplin dan langkah untuk meminimalisir resiko perbankan.

Dewan Syariah Nasional-Majelis Ulama Indonesia (DSN-MUI) melalui Dewan Pengawas Syariah (DPS) adalah pihak yang ditugaskan untuk memastikan bahwa pemenuhan prinsip syariah di sektor ekonomi, khususnya perbankan syariah, dijalankan secara maksimal. Namun dalam praktiknya, pengawasan yang dilakukan oleh DPS belum maksimal, dan masih menunjukkan adanya beberapa pelanggaran syariah di perbankan syariah.

Pelanggaran shariah complience merupakan dampak dari tidak optimalnya peran dan fungsi DPS atau luput dari pengawasan DPS, yang berakibat pada rusaknya citra dan kredibilitas bank syariah di mata masyarakat, sehingga dapat menurunkan kepercayaan masyarakat kepada bank syariah yang bersangkutan.Untuk itulah peran DPS di bank syariah harus benar-benar dioptimalkan.

\section{B. Tinjuan Pustaka}

Secara sederhana bank merupakan sebuah lembaga intermediasi yang memberikan fasilitas pelayanan keuangan pada masyarkat. Dalam perkembangannya sistem perbankan di Indonesia terbagi menjadi dua yakni bank syariah dan bank konvensional. dalam beberapa hal bank syariah dan bank konvensional memiliki persamaan terutama dalam hal sisi teknis penerimaan uang, mekanisme transfer, syarat-syarat umum dalam pembukaan

\footnotetext{
8Bank Indonesia, Peraturan Bank Indonesia Nomor 13/2/PBI/2011 Tentang Pelaksanaan Fungsi Kepatuhan Bank Umum.
} 
simpanan maupun dalam mendapatkan pembiayaan. ${ }^{9}$ Akan tetapi terdapat perbedaan mendasar (prinsip) di antara bank syariah dengan bank konvensional yakni terkait tentang penerapan dan kepatuhan syariah yang harus melekat pada bank syariah.

Bank konvensional adalah sebuah institusi bisnis yang bernafaskan atas dasar prinsip ekonomi barat, sehingga keuntungan hanyalah diterjemahkan dalam tataran dan aspek material belaka, sementara bank syariah adalah sebuah prinsip perbankan yang dilandaskan pada nilai-nilai Islami, sehingga tidak hanya menghendaki keuntungan material, namun juga keuntungan spritual. Sehingga identitas bank Islam yang mengharapakan keuntungan ganda adalah sebuah ciri khas yang melekat dalam bank syariah itu sendiri. ${ }^{10}$

Menurut Undang-Undang Nomor 21 Tahun 2008 pasal 1 ayat (1) Pebankan Syariah adalah segala sesuatu yang menyangkut tentang Bank Syariah dan Unit Usaha Syariah, mencakup kelembagaan, kegiatan usaha, serta cara dan proses dalam melaksanakan kegiatan usahanya. Kemudian dalam Pasal 1 ayat (7) disebutkan bahwa Bank Syariah adalah bank yang menjalankan kegiatan usahanya berdasarkan prinsip syariah dan menurut jenisnya sendiri atau Bank Umum Syariah dan Bank Pembiayaan Rakyat Syariah. Kemudian dalam pasal 1 ayat (12), menyebutkan bahwa prinsip syariah adalah prinsip hukum Islam dalam kegiatan perbankan berdasarkan fatwa yang dikeluarkan oleh lembaga yang memiliki kewenanga dalam penetapan fatwa di bidang syariah. ${ }^{11}$

Kepatuhan syariah dalam bank syariah adalah penerapan prinsipprinsip Islam, syariah dan tradisinya dalam transaksi keuangan dan perbankan serta bisnis lain yang terkait. Sistem keuangan Islam secara substansial berbeda dari industri keuangan yang masih menggunakan sistem

\footnotetext{
${ }^{9}$ Kautsar Riza Salman, Akuntansi Perbankan Syariah Berbasis PSAK Syariah (Padang: Akademia Permata, 2012), hlm. 60.

${ }^{10}$ Sumar'in, Konsep Kelembagan Bank Syariah (Yogyakarta: Graha Ilmu, 2012), hlm. 58.

${ }^{11}$ Undang-Undang Nomor 21 Tahun 2008 tentang Pebankan Syariah.
} 
konvensional. Ada kaitan yang erat antara aspek konseptual dan praktis dari aktivitas bisnis keuangan dan prinsip-prinsip Islam atau syariah. Dengan kata lain, salah satu aspek mendasar yang membedakan industri keuangan syariah dan konvensional adalah perihal kepatuhan pada prinsip syariah (sharia compliance). ${ }^{12}$

Menurut Zainal Kepatuhan syariah dalam bank syariah adalah penerapan prinsip-prinsip Islam, syariah dan tradisinya dalam transaksi keuangan dan perbankan serta bisnis lain yang terkait. ${ }^{13} \mathrm{Hal}$ ini menggambarkan bahwa pelaksanaan kepatuhan syariah adalah suatu bentuk aktivitas holistik dari kegiatan bank syariah, yang tidak hanya berbicara produk, akad tapi juga bicara budaya kerja, tradisi, traksaksi serta semua aktivitas kegiatan bank syariah. Adapun konsep dasar fungsi kepatuhan yakni berfungsi sebagai pelaksana dan pengelola risiko kepatuhan yang berkoordinasi dengan satuan kerja dalam manajemen resiko. Fungsi kepatuhan melakukan tugas pengawasan yang bersifat preventif dan menjadi elemen penting dalam pengelolaan dan operasional bank syariah. ${ }^{14}$ Sehingga dalam perbankan syariah sendiri yang dimaksud dengan sharia compliance yaitu meningkatkan pengetahuan syariah bagi karyawan sehingga peluang terjadinya pelanggaran syariah akan dapat diminimalisir dan mampu menciptakan tawaran-tawaran produk dan layanan yang kreatif dan inovatif, namun tetap patuh pada aspek syariah.

Lebih lanjut menurut Menurut Adrian Sutedi, kepatuhan syariah dalam operasional bank syariah tidak hanya meliputi produk saja, akan tetapi meliputi sistem, teknik dan identitas perusahaan. Karena itu, budaya perusahaan yang meliputi pakaian, dekorasi dan image perusahaan merupakan

${ }^{12}$ Abdullah M. Noman, "Imperatives of Financial Innovations For Islamic Banks", International Journal of Islamic Financial Services, Vol. 3, (2003), hlm. 5-18

${ }^{13}$ Zainal Arifin, Dasar..., hlm. 2.

${ }^{14}$ Haniah Ilhami, Pertanggungjawaban Dewan Pengurus Syariah Sebagai Otoritas Pengawas Kepatuhan Syariah Bagi Bank Syariah, Jurnal Mimbar Hukum, Volume 21 Nomor 3, Oktober 2009, hlm. 477 
salah satu aspek kepatuhan syariah dalam bank syariah. Tujuannya, tidak lain untuk menciptakan suatu moralitas dan spiritual kolektif, yang apabila digabungkan dengan produksi barang dan jasa, maka akan menopang kemajuan dan pertumbuhan jalan hidup yang islami. ${ }^{15}$

Konteks dalam Perbankan Syariah, memaknai bahwa kepatuhan syariah adalah suatu makna yang luas mencakup meningkatkan pengetahuan syariah bagi karyawan sehingga peluang terjadinya pelanggaran syariah berkurang, selain itu menciptakan tawaran-tawaran produk dan layanan yang kreaktif dan inovatif, namun tetap patuh pada aturan DSN-MUI. Artinya penerapan kepatuhan syariah harus difahami secara komprehensif.

Berdasarkan penelitian Agus Triyanta tentang “Implementasi Kepatuhan Syariah dalam Perbankan Islam (Syariah) studi perbandingan antara Malaysia dan Indonesia". Dalam penelitiannya tersebut, dijelaskan bahwa keberadaan Dewan Pengawas Syariah (DPS) sangatlah dibutuhkan pada Lembaga Keuangan Syariah sebagai jaminan atas operasional lembagalembaga keuangan syariah agar benar-benar sesuai dengan syariah, sebagaimana yang telah diaplikasikan di Indonesia maupun Malaysia walaupun ada beberapa perbedaan antara penerapan di Indonesia dengan di Malaysia. ${ }^{16}$

Penerapan kepatuhan syariah adalah suatu hal yang mau tidak mau harus dilakukan dan dijaga oleh pihak bank syariah. Karena penerapan kepatuhan syariah merupakan suatu aspek yang akan menjaga reputasi bank. Artinya jika bank syariah dianggap tidak menerapkan prinsip syariah maka secara otomatis reputasi bank tersebut telah jatuh dimata nasabah. Berdasarkan penelitian yang dilakukan oleh Ganesan terkait tentang pengaruh

${ }^{15}$ Adrian Sutedi, Perbakan ..., hlm. 145.

${ }^{16}$ Agus Triyanta, "Implementasi Kepatuhan Syariah dalam Perbankan Islam (Syariah) (studi perbandingan antara Malaysia dan Indonesia)", IIUM (International Islamic University of Malaysia) dalam Jurnal Hukum No. Edisi Khusus Vol.16 Oktober 2009, Unversitas Islam Indonesia, hlm 209-228. 
reputasi terhadap dasar penilaian dalam menentukan apakah suatu perusahaan layak untuk dijadikan mitra kerjasama, hasil penelitian tersebut menunjukkan pengaruh positif antara reputasi dengan kepercayaan yang pada akhirnya akan mengarah pada terciptanya hubungan jangka panjang antara bank dengan nasabah. ${ }^{17}$ Hasil penelitian Saxton juga menunjukkan hasil yang sama bahwa reputasi berhubungan positif terhadap kepercayaan masyarakat untuk bekerjasama pada suatu instansi perusahaan. ${ }^{18}$ Melihat betapa pentingnya penerapan syariah bagi sebuah lembaga perbankan syariah oleh itu penting kiranya untuk memberikan penguatan pada aspek tersebut yang dalam hal ini dilakukan oleh pihak DPS.

\section{Metodologi}

Penelitian ini menggunakan metode penelitian library researc (penelitian pustaka). Sumber data dalam penelitian ini adalah bahan kepustakaan yang menjadi referensi utama yang berkaitan dengan tema tulisan ini. Oleh karena itu, untuk mengumpulkan data-data yang diperlukan dalam penelitian ini, penulis melakukan penelusuran terhadap bahan-bahan kepustakaan seperti, artikel, jurnal, kitab-kitab dan buku-buku serta literatur yang ada kaitannya dengan pembahasan masalah ini untuk kemudian ditelaah atau dianalisa. Adapun analisis dilakukan dengan pendekatan deskriptik analitik, ${ }^{19}$ artinya peneliti berusaha untuk mendeskripsikan dan memecahkan masalah yang diselidiki.

\footnotetext{
${ }^{17}$ Shankar Ganesan, "Determinants of Long-term Orientation in Buyer-Seller Relationship", Journal of Marketing, No.58, April, 1994, hlm. 1-19.

18Todd Saxton, "The Effects of Partner and Relationship Characteristic on Alliance Outcomes", Academy of Management Journal, Vol. 40, No.2, 1997, hlm. 443-461.

${ }^{19}$ Syayfudin Azwar, Metode Penelitian, cet ke-2 (Yogyakarta: Pustaka Pelajar, 1999), hlm.126.
} 


\section{Pembahasan}

Berbicara tentang sharia compliance sesungguhnya berbicara tentang keunikan dan beda antara bank syariah dan bank konvensional. Karena hal esensi dari penerapan kepatuhan syariah adalah menjadi keunikan dan ciri khas dari nilai Islam pada lembaga tersebut. Dalam beberapa hal bank syariah dan bank konvensional memiliki persamaan terutama dalam hal sisi teknis penerimaan uang, mekanisme transfer, syarat-syarat umum dalam pembukaan simpanan maupun dalam mendapatkan pembiayaan. ${ }^{20}$ Akan tetapi terdapat perbedaan mendasar (prinsip) di antara bank syariah dengan bank konvensional, yaitu: ${ }^{21}$

Tabel 1.1 Perbedaan bank syariah dan bank konvensional

\begin{tabular}{|c|c|c|}
\hline Karakteristik & Sistem Bank Syariah & Sistem Bank Konvensional \\
\hline \multirow[t]{3}{*}{$\begin{array}{l}\text { Kerangka } \\
\text { Bisnis }\end{array}$} & $\begin{array}{ll}\text { Berdasarkan pada } & \text { nilai-nilai } \\
\text { Islam sebagai } & \text { Landasan } \\
\text { Filosofis } & \end{array}$ & $\begin{array}{l}\text { Prinsip Ekonomi (barat) } \\
\text { dijadiakan sebagai Landasan } \\
\text { Filosofis }\end{array}$ \\
\hline & $\begin{array}{l}\text { Menjadi Maslahah sebagai } \\
\text { tujuan untuk mencapai Falah }\end{array}$ & $\begin{array}{l}\text { Kegiatan bisnis dilandaskan } \\
\text { pada orientasi keuntungan }\end{array}$ \\
\hline & $\begin{array}{l}\text { Meninggalkan segala bentuk } \\
\text { aktivitas yang bertentangan } \\
\text { dengan nilai agama }\end{array}$ & Optimal \\
\hline \multirow{2}{*}{$\begin{array}{l}\text { Landasan } \\
\text { Hukum }\end{array}$} & Hukum Syariah & \multirow[t]{2}{*}{ Undang-undang Perbankan } \\
\hline & Undang-undang Perbankan & \\
\hline \multirow[t]{2}{*}{$\begin{array}{l}\text { Imbalan } \\
\text { Hasil }\end{array}$} & $\begin{array}{l}\text { Prinsip Bagi Hasil dan Margin } \\
\text { keuntungan yang jelas }\end{array}$ & bunga \\
\hline & $\begin{array}{l}\text { Disepakati secara bersama- } \\
\text { sama }\end{array}$ & $\begin{array}{l}\text { Fluktuatif dan sesuai dengan } \\
\text { tingkat suku bunga }\end{array}$ \\
\hline \multirow[t]{2}{*}{$\begin{array}{l}\text { Bentuk } \\
\text { Transaksi }\end{array}$} & $\begin{array}{l}\text { Akad yang jelas sesuai dengan } \\
\text { kesepakatan bersama }\end{array}$ & \multirow[t]{2}{*}{$\begin{array}{l}\text { Uang boleh digunakan sesuai } \\
\text { keinginan }\end{array}$} \\
\hline & $\begin{array}{l}\text { Menjunung tinggi hak dan } \\
\text { kewajiban sesuai akad }\end{array}$ & \\
\hline \multirow[t]{2}{*}{ Sektor Bisnis } & $\begin{array}{ll}\text { Optimalisasi } & \text { Pembiayaan } \\
\text { Sektor riil } & \\
\end{array}$ & $\begin{array}{l}\text { Sektor keuangan dan pasar } \\
\text { derivatif }\end{array}$ \\
\hline & Melihat karakteristik usaha & Semua perusahaan dan usaha \\
\hline
\end{tabular}

${ }^{20}$ Kautsar Riza Salman, Akuntansi Perbankan ... , hlm. 60.

${ }^{21 S u m a r ' i n, ~ K o n s e p ~ K e l e m b a g a a n ~ . . . ~, ~ h l m . ~ 58-59 . ~}$ 


\begin{tabular}{|l|l|l|}
\hline \multirow{2}{*}{ Denda } & $\begin{array}{l}\text { dan Perusahaan yang sesuai } \\
\text { syariah }\end{array}$ & $\begin{array}{l}\text { yang dianggap } \\
\text { menguntungkan }\end{array}$ \\
\hline & $\begin{array}{l}\text { Diambil sesuai ketentuan } \\
\text { dengan prinsip pendidikan } \\
\text { dan penegasan }\end{array}$ & $\begin{array}{l}\text { Diambil sesuai pelanggaran } \\
\text { yang dilakukan }\end{array}$ \\
\cline { 2 - 3 } & $\begin{array}{l}\text { Dihitung sebagai bukan } \\
\text { pendapatan (pendapatan non } \\
\text { halal) }\end{array}$ & $\begin{array}{l}\text { Dihitung sebagai bagian dari } \\
\text { pendapatan bank }\end{array}$ \\
\hline $\begin{array}{l}\text { Penyelesaian } \\
\text { Sengketa }\end{array}$ & Pengadilan & Pengadilan \\
\cline { 2 - 3 } $\begin{array}{l}\text { Hubungan } \\
\text { bisnis }\end{array}$ & Kemitraan Arbitrase Syariah & Arbitrase \\
\cline { 2 - 3 } Pelayanan & Perdagangan dan penjual & Kreditor dan Debitor \\
\hline Pengawasan & Etika Bisnis Islami & $\begin{array}{l}\text { Etika bisnis yang berorientasi } \\
\text { keuntungan material }\end{array}$ \\
\cline { 2 - 3 } & Manajemen Prudensial & Manajemen Prudensial \\
\hline
\end{tabular}

Melihat detail dan bedanya bank syariah dengan bank konvensional ini, menjadi tanggung jawab semua pihak untuk menjaga dan mengawasi agar bank syariah tetap pada prinsip dan nilai-nilai syariah. Pengawasan merupakan salah satu dari fungsi manajemen. Adanya pengawasan agar menjamin terlaksananya sebuah kegiatan dengan konsisten, sehingga tujuan dari kegiatan tersebut dapat tercapai dengan baik. Penjagaan dan pengawasan dalam pandangan Islam dilakukan untuk meluruskan yang tidak lurus, mengoreksi yang salah, dan membenarkan yang hak.

- Pengawasan dalam Islam mempunyai karakteristik antara lain: pengawasan bersifat material dan spiritual, monitoring bukan hanya manajer, tetapi juga Allah Swt, menggunakan metode yang benar sesuai prinsip Islam yang menjunjung martabat manusia. Dengan karakterisrik tersebut dapat dipahami bahwa pelaksana berbagai perencanaan yang telah disepakati akan bertanggung jawab kepada tidak hanya pada pimpinan dunia tapi juga Allah swt. Di sisi lain pengawasan dalam konsep Islam lebih mengutamakan menggunakan pendekatan manusiawi, pendekatan yang dijiwai oleh nilai-nilai keislaman dan tanggung jawab. 
Pengawasan (control) dalam ajaran Islam paling tidak terbagi dalam dua hal, yaitu Pertama, control yang berasal dari diri sendiri yang bersumber dari tauhid dan keimanan kepada Allah Swt. Seseorang yang yakin bahwa Allah mengawasi hambaNya, maka ia akan bertindak hati-hati. ${ }^{22}$

Kedua, sebuah pengawasan akan lebih efektif jika sistem pengawasan tersebut juga dilakukan dari pihak luar. Bisa berasal dari pimpinan, yang menyangkut tugas yang didelegasikan, kesesuaian penyelesaian dan perencanaannya, dan lain-lain. Oleh itu penerapan syariah compliance adalah suatu mekanisme dari satu kesatuan dalam seluruh aktivitas bank syariah. Meskipun dalam penerapannya menjadi tanggung jawab oleh DPS, namun bukan berarti peran unit-unit lain terabaikan dalam penerapan syariah compliance ini.

Kepatuhan syariah (sharia compliance) merupakan bentuk pemenuhan seluruh prinsip-prinsip syariah dalam lembaga yang memiliki wujud, karakteristik, integritas dan kredibilitas di bank syariah. Kepatuhan syariah tersebut merupakan perwujudan nilai, perilaku dan tindakan yang mendukung terciptanya kepatuhan bank syariah terhadap seluruh ketentuanketentuan syariah islam, yang dalam hal ini secara regulasi perbankan syariah dijelaskan dalam Undang-Undang Nomor 21 tahun 2008 tentang perbank syariah. Undang Undang tersebut merupakan sebuah dukungan penguatan kelembagaan dalam memberikan layanan serta kepercayaan kepada masyarakat akan eksistensi bank syariah.

Fungsi kepatuhan syariah dalam perbankan syariah erat kaitannya dengan peran dan fungsi dewan pengawas syariah di masing-masing lembaga keuangan syariah. Kepatuhan syariah (shariah compliance) memiliki standar internasional yang disusun dan ditetapkan oleh Islamic Financial Service Board

${ }^{22}$ Q.S. Al-Mujadalah: 7 
(IFSB) dimana kepatuhan syariah merupakan bagian dari tata kelola lembaga (corporate governance).

Penerapan syariah compliance dalam perbankan syariah sesungguhnya dilimpahkan pada satu lembaga syariah. Lembaga tersebut merupakan satu elemen kunci yang berfungsi sebagai regulator dalam mengeluarkan kebijakan, aturan, tata kerja yang dijalankan dalam praktek dunia perbankan syariah. Instrument tersebut adalah Dewan pengawas syariah (DPS). Di Indonesia, tingkat pengawasan pertama dinamai dengan Dewan Pengawas Syariah (DPS) dan tingkat pengawasan berikutnya di level nasional dinamai dengan Dewan Syariah Nasional (DSN). ${ }^{23}$

Dewan pengawas syariah (DPS) ditetapkan melalui persetujuan Dewan Syariah nasional (DSN) merupakan sebuah badan yang dibentuk secara khusus oleh Majelis Ulama Indonesia (MUI). DSN adalah lembaga yang berfungsi untuk melaksanakan tugas-tugas MUI dalam menangani masalah-masalah yang berhubungan dengan aktivitas lembaga keuangan syariah. DSN terdiri dari beberapa ulama, praktisi, maupun pakar ekonomi syariah yang sebelumnya ditunjuk dan diangkat oleh MUI dengan masa bakti kepengurusan selama lima (5) tahun. DSN memiliki tanggung jawab dalam memastikan atau mengawal kepatuhan syariah, baik dalam produk maupun operasional dari industri keuangan syariah itu sendiri. Untuk mendukung para anggota dewan syariah dalam menjalankan tugasnya, DSN menyiapkan aturan yang diperlukan, terkait dengan kualifikasi keanggotaan, tugas dan kewajiban, pengakuan fatwa yang diterbitkan, serta independensi mereka dari berbagai intervensi dari berbagai pihak. ${ }^{24}$

${ }^{23}$ Didin Hafidhuddin dan Hendri Tanjung, Manajemen Syariah dalam Praktik, (Jakarta: Gema Insani Press, 2003) hlm. 39

${ }^{24}$ Lihat Surat Edaran Gubernur Bank Indonesia No. 8/19/DPBS tentang Pedoman Pengawasan Syariah dan TataCara Pelaporan Hasil Pengawasan bagi Dewan Pengawas Syariah. 
Tugas DSN adalah mengawasi produk-produk lembaga keuangan syariah agar sesuai dangan ketentuan-ketentuan yang ada di dalam syariah. Maka dari itu, DSN membuat aturan dalam bentuk guidelines dengan mengkaji, menggali, dan merumuskan nilai-nilai dan prinsip-prinsip syariah yang mana dalam bentuk fatwa untuk dijadikan pedoman dalam kegiatan transaksi dan analisis produk dan jasa di lembaga keuangan syariah. Secara rinci, berikut tugas dan wewenang daripada DSN, yaitu: ${ }^{25}$

1. memberikan atau mencabut rekomendasi nama-nama yang akan duduk sebagai anggota DPS pada suatu lembaga keuangan syariah;

2. mengeluarkan fatwa atas jenis-jenis kegiatan keuangan;

3. mengeluarkan fatwa atas produk dan jasa keuangan syariah;

4. mengawasi penerapan fatwa yang telah diterapkan.

DPS yang menjadi perpanjangan tangan DSN akan memiliki peran sebagai pengawal syariah compliance dalam operasional lembaga keuangan syariah yang diawasinya. Fungsi utama DPS adalah sebagai penasehat dan pemberi saran kepada direksi, pimpinan unit usaha syariah dan pimpinan kantor cabang syariah mengenai hal-hal yang terkait dengan aspek syariah, dan juga sebagai mediator antara lembaga keuangan syariah dengan DSN dalam mengkomunikasikan usul dan saran pengembangan produk dan jasa dari lembaga keuangan syariah yang memerlukan kajian dan fatwa dari DSN.

DPS memiliki peranan penting dalam meminimalisir dan menghindari adanya kemungkinan penyimpangan terhadap kepatuhan syariah (sharia compliance). Melalui pengawasan tersebut, maka DPS diharapkan dapat membantu untuk mengevaluasi dan mendeteksi sejauhmana pelaksanaan atau implementasi kepatuhan syariah ditetapkan dan sejauhmana penyimpangan yang terjadi dalam mengevaluasi kepatuhan syariah oleh industri keuangan

${ }^{25}$ Rizal Yahya dkk., Akuntansi Perbankan Syariah Teori dan Praktik Kontemporer, (Jakarta: Salemba Empat, 2009), hlm. 27 
syariah atas prinsip-prinsip syariah. Keberadaan dari DPS diharapkan dapat memfokuskan dirinya dalam mengembangkan dan mengawal industri keuangan syariah atas produk yang dikeluarkan maupun operasional yang bersangkutan yang diawasinya agar selalu berjalan sesuai dengan prinsipprinsip yang ada di dalam koridor syariah

Tugas Dewan Pengawas Syariah (DPS) adalah memberikan nasehat dan saran kepada direksi serta mengawasi kegiatan bank agar sesuai dengan perinsip syariah. Dalam penjelasan pasal 32 ayat (4) hal-hal mengenai a) ruang lingkup, tugas dan fungsi Dewan Pengawas Syariah; b) jumlah anggota Dewan Pengawas Syariah, harus diatur dalam Peraturan Bank Indonesia.

Menurut Standar AAOIFI, anggota DPS setidaknya harus terdiri atas tiga orang cendekiawan syariah. ${ }^{26}$ yang diangkat berdasarkan Rapat Umum Pemegang Saham (RUPS) dan dalam keadaan tidak merangkap jabatan sebagai konsultan di seluruh Bank Umum Syariah dan Unit Usaha Syariah. Hal ini perlu dilakukan karena DPS sebagai badan independen dapat terlepas dari konflik kepentingan. Dalam pelaksanaan tugasnya, diatur dalam Pasal 46 PBI No.11/33/ PBI/2009 tentang Pelaksanaan GCG bagi Bank Umum Syariah dan Unit Usaha Syariah. Berikut adalah tugas dan tanggungjawab DPS:27

1. DPS wajib melaksanakan tugas dan tanggung jawab sesuai dengan prinsip-prinsip GCG.

2. Tugas dan tanggungjawab DPS adalah memberikan nasihat dan saran kepada Direksi serta mengawasi kegiatan bank agar sesuai dengan prinsip syariah.

3. Pelaksanaan tugas dan tanggung jawab DPS sebagaimana dimaksud pada ayat (1) meliputi antara lain:

${ }_{26}$ Muhammad Ayub, Understanding Islamic Finance, (Jakarta: PT Gramedia Pustaka Utama, 2009), hlm. 590

${ }^{27}$ Lihat PBI No. 11/03/2009 Tentang Bank Umum Syariah. 
a. menilai dan memastikan pemenuhan Prinsip Syariah atas pedoman operasional dan produk yang dikeluarkan Bank;

b. mengawasi proses pengembangan produk baru Bank;

c. meminta fatwa kepada Dewan Syariah Nasional untuk produk baru Bank yang belum ada fatwanya;

d. melakukan review secara berkala atas pemenuhan prinsip syariah terhadap mekanisme penghimpunan dana dan penyaluran dana serta pelayanan jasa bank; dan

e. meminta data dan informasi terkait dengan aspek syariah dari satuan kerja Bank dalam rangka pelaksanaan tugasnya.

4. DPS wajib menyampaikan Laporan Hasil Pengawasan DPS secara semesteran yang disampaikan kepada Bank Indonesia paling lambat dua bulan setelah periode semester dimaksud berakhir. Dalam laporannya dibuat pernyataan bahwa bank yang diawasinya telah berjalan sesuai dengan ketentuan syariah. Pernyataan ini kemudian dimuat dalam laporan keuangan bank.

5. Dari segi kinerja bisa jadi tugas DPS lebih berat dari Dewan Komisaris. Hal ini bisa dilihat dari jumlah rapat yang wajib dilakukan oleh DPS dibandingkan oleh Dewan Komisaris. Dalam Pasal 49 ayat 1 PBI No.11/33/PBI/2009 tentang Pelaksanaan GCG bagi Bank Umum Syariah dan Unit Usaha Syariah disebutkan bahwa rapat DPS wajib diselenggarakan paling kurang satu kali dalam satu bulan. Sedangkan bagi Dewan Komisaris wajib diselenggarakan paling kurang satu kali dalam dua bulan

Terkait dengan proses pengawalan kepatuhan syariah, proses pengawalan kepatuhan syariah oleh DPS mengikuti aturan yang telah ditetapkan oleh Accounting And Auditing Organization for Islamic Financial Institutions (AAOIFI) dan Islamic Financial Services Board (IFSB), yang 
menegaskan adanya pengawasan sebelum bisnis dijalankan (ex ante) dan setelah bisnis dijalankan (ex post).

Dewan Pengawas Syariah (DPS) mengemban tugas dan tanggungjawab besar dan berfungsi sebagai bagian stakeholders, karena mereka adalah pelindung hak investor dan pengusaha yang meletakkan keyakinan dan kepercayaan dalam institusi finansial. Dalam analisis penulis setidaknya terdapat beberapa 3 (tiga) isu strategis yang harus diperbaiki dalam kaitannya dengan tugas DPS yakni masalah kompetensi dan kualifikasi, masalah independen, serta masalah prosedur pelaksanaan audit syariah.

Pertama Masalah kompetensi dan kualifikasi ini menjadi masalah utama yang mestinya harus benar-benar diatasi. Fakta di lapangan ditemukan bahwa pengangkatan DPS bukan didasarkan pada keilmuannya, sehingga fungsi pengawasan DPS tidak optimal, akibatnya penyimpangan dari praktik syariah menjadi hal yang mungkin dan sering terjadi. Oleh itu, sistem seleksi, kompetensi dan kualifikasi terhadap DPS harus distandarisasikan oleh pihak OJK, hal ini dengan harapan DPS benar-benar orang pilihan yang mempunyai kualifiasi dan kompetensi baik secara ilmu ekonomi, maupun ilmu agama khususnya tentang syariah yang relevan dalam menunjang pekerjaannya sebagai pengawas internal di bank syariah.

Kesalahan bank-bank syariah di Indonesia mengangkat DPS, yakni mengangkat orang yang sangat terkenal di ormas Islam atau terkenal dalam ilmu keislaman (bukan syari'ah), tetapi tidak berkompeten dalam bidang perbankan dan keuangan syariah merupakan bahaya latin yang harus segera hilangkan. DPS bagi sebagian bank hanya dijadikan sebagai alat promosi untuk memperkenalkan bank. Sebagian DPS tidak mengerti operasional perbankan syariah dan tidak optimal mengawasi bank syariah.

Realita ini sesungguhnya menguntungkan bagi pihak manajemen perbankan syariah, karena mereka lebih bebas berbuat apa saja, karena pengawasannya sangat longgar. Tetapi dalam jangka panjang hal ini justru 
merugikan gerakan ekonomi syariah, tidak saja bagi bank syariah yang bersangkutan tetapi juga bagi gerakan ekonomi dan bank syariah secara keseluruhan dan kemajuan bank syariah di masa depan. Karena itu tidak aneh jika masih banyak masyarakat Indonesia yang memandang bahwa bank syariah sama dengan bank konvensional

Kemampuan Fiqih yang dimiliki oleh DPS tidak diimbangi dengan kemampuan dan pengetahuan dibidang perbankan juga merupakan hal biasa yang ditemukan dari beberapa DPS, sehingga berkemungkinan akan memposisikan DPS kepada dua opsi. Pertama, DPS akan selalu berpijak kepada prinsip syariah dan memegang teguh kaidah-kaidah fiqih, sehingga dari sisi bisnis perbankan tidak terpikirkan bagaimana julan produk yang bisa diminati oleh nasabah sehingga produk tidak bisa bersaing di pasaran sehingga marketing produk juga akan terdampak. Kedua, jika DPS tidak mengetahui siklus perbankan secara keseluruhan dan tidak melakukan pengawasan secara optimal, hal ini akan menguntungkan manajemen karena mereka lebih bebas berbuat apa saja, karena pengawasannya sangat longgar. Dalam jangka panjang, dua opsi tersebut akan merugikan gerakan ekonomi syariah kedepan. Oleh itu, dalam analisis penulis, sistem seleksi dan pengangkatan DPS harus dievaluasi oleh pihak OJK, dalam upaya menjaga syariah compliance di perbankan syariah.

Kedua masalah Independensi, bahwa Dewan Pengawas Syariah (DPS) adalah pihak yang memberikan jaminan kepada masyarakat terhadap kemurnian nilai-nilai syariah di lembaga keuangan syariah, namun dilain pihak mereka juga dihadapkan pada objektivitas dan independensi sebagai pegawai yang juga mendapatkan fasilitas dan gaji dari pihak perbankan tersebut. Keterkaitan struktur ini menyebabkan DPS akan kesulitan untuk bersikap independen secara mental untuk memberikan pengawasan yang objektiv terhadap produk dan operasional dari bank bersangkutan. Walaupun, ini 
secara individu secara subyektif bisa dilakukan, namun relative sulit untuk diukur dan dibuktikan.

Selanjutnya, independensi DPS terhadap DSN. Saat ini, beberapa DPS juga merangkat menjadi pengurus di DSN. Kondisi ini akan menimbulkan konflik kepentingan saat DPS yang rangkap jabatan tersebut mengajukan permohonan fatwa kepada DSN. Idealnya, pemisahan DSN dan DPS seperti yang ditunjukkan antara BI atau OJK dengan bank, dimana tidak ada pegawai BI atau OJK yang membuat regulasi yang merangkap sebagai karyawan di bank. Oleh itu, perlunya diatur bagaimana mestinya pihak DPS adalah badan otonom yang terpisah dari manajemen bank, bahwa mereka adalah pihak yang menadapatkan fasilitas dari OJK atau BI, bukan dari bank secara langsung. Selain itu, perlunya aturan yang tegas pada pihak DPS untuk bersikap independen, dan bukan bagian dari DSN karena mereka adalah pihak yang mestinya ditunjuk oleh DSN bukan bagian dari orang DSN.

Ketiga adalah masalah prosedur pelaksanaan audit syariah, bahwa pengembangan perbankan syariah merupakan suatu hal yang patut untuk di apresiasi, namun disisi lain harusnya juga diikuti dengan penerapan prinsip kehatian-hatian (prudential) dalam setiap aktivitas utamanya terkait masalah pembiayaan yang bermasalah (NPF), harus dapat terus diminimalisir. Keinginan untuk terus berkembang dan mendapatkan keuntungan yang lebih besar harus diimbangi dengan ketelitian dan kehati-hatian dalam mengelola dana perbankan sehingga perkembangan perbankan syariah dapat terus terjaga stabilitasnya. Sehingga terkait masalah prosedur pelaksanaan audit syariah juga harus benar-benar diperhatikan dalam menjaga kridebilitas DPS di sebuah lembaga perbankan.

Selain itu masalah ketiga terkait dengan prosedur pelaksanaan audit syariah juga berhubungan dengan masalah akad dan prosedur pembiayaah. Bahwa perbankan syariah sangat rentan terhadap kesalahan-kesalahan yang bersifat prinsip utamanya terkait tentang masalah akad dan prosedur 
pembiayaan. Tuntutan target, tingkat keuntungan yang lebih baik, serta penilaian kinerja pada setiap cabang bank syari'ah, yang masih dominan didasarkan atas kinerja keuangan, akan dapat mendorong para pelaku dan praktisi untuk melanggar ketentuan syari'ah. Hal ini akan semakin rentan terjadi pada bank syari'ah dengan tingkat pengawasan syariah yang rendah. Oleh karenanya, tidak heran, jika masih banyak ditemukannya pelanggaran aspek syari'ah yang dilakukan oleh lembaga-lembaga perbankan syariah, khususnya perbankan yang konversi ke syariah atau membuka unit usaha syariah. Oleh itu dalam upaya menjaga dan meningkatkan prosedur kepatuhan syariah disuatu bank, pihak manajemen atau OJK harus membuat aturan yang ketat tentang standar audit internal yang dilakukan oleh DPS.

Merujuk pada pendapat Makmur dalam melakukan pengawasan ada beberapa teknik yang harus diperhatikan agar pengawasan utamanya DPS yang dilakukan bisa berjalan maksimal, diantaranya:28

1. Pemantauan dalam pengawasan. Pemantauan yang dilakukan secara langsung atau tidak langsung, agar program yang direncanakan bisa diimplementasikan dengan baik.

2. Pemeriksaan dalam pengawasan. Teknik pemeriksaan dalam pengawasan harus dapat memberikan informasi atau keterangan yang jelas dengan mengandung kebenaran.

3. Penilaian dalam pengawasan. Penilaian sebagai bagian dari pengawasan harus dilakukan dengan jujur dan adil. Jiwa utamanya adalah kebenaran, karena penilaian akan sangat berakibat negatif.

4. Wawancara dalam pengawasan.Wawancara dalam pengawasan dilakukan dalam rangka memperoleh informasi sehingga pengawas bisa menentukan suatu keyakinan dari kebenaran dalam pelaksanaan suatu kegiatan yang sesuai dengan rencana awal.

${ }^{28}$ Makmur, Efektivitas Kebijakan Kelembagaan Pengawasan, (Bandung; Rfika Aditama, 2011) hlm. 195. 
5. Pengamatan dalam pengawasan. Hal ini dilakukan untuk membuktikan antara data yang diamati dengan yang sesungguhnya terjadi.

6. Analisis dalam pengawasan. Setiap data yang diperoleh dari hasil pengawasan harus dilakukan analisis untuk menentukan kualitas hasil pekerjaan yang dilakukan oleh satuan unit kerja.

7. Pelaporan dalam pengawasan. Sebagaimana yang kita ketahui bahwa setiap pelaksanaan kegiatan dalam berbagai kelembagaan selalu memberikan laporan dari apa yang telah dikerjakan, begitu juga dalam sebuah pengawasan.

Lebih lanjut merujuk pada pendapat Agustianto, agar DPS dan DSN memiliki peran yang optimal dan signifikan, setidaknya ada lima hal penting yang harus menjadi perhatian bersama:29

1. MUI menentukan klasifikasi keahlian pihak-pihak yang dapat diangkat menjadi anggota DSN atau DPS. Seperti di Sudan, Abdallah (1994) menyatakan bahwa anggota Department of Fatwa and Research (DFR) dan Higher Sharia Supervisory Board (HSSB) adalah orang-orang yang mempunyai keahlian di bidang Syariah (Islamic Jurisprudence), hukum dan ekonomi (akuntansi).

2. Bank Indonesia sudah mengeluarkan PBI (Peraturan bank Indonesia), tahun 2010 tentang Good Corporate Governance Bank Umum Syariah dan UUS. Salah isinya adalah mengatur tentang peran dan kedudukan Dewan Pengawas Syariah. Menurut PBI tersebut, seorang konsultan bank syariah tidak boleh menjadi Dewan pengawas Syariah, hal ini bertujuan agar terjadi pola hubungan yang fair antara konsultan, DPS dan bank syariah. Dalam masa transisi, dimana Indonesia masih kekurangan SDM, DSN MUI dan Bank Indonesia telah melakukan berbagai terobosan program dan juga kegiatan dalam rangka menambah jumlah sumber daya manusia yang ahli dalam

${ }^{29}$ Agustianto, “Optimalisasi Peranan Dewan Pengawas Syari'ah", dikutip dari http://www.agustiantocentre.com/, tanggal 2 Mei 2017. 
bidang ekonomi syariah, seperti sertifikasi, annual meeting, seminar, workshop dan sebagainya.

3. Model pengawasan DPS pasca keluaranya PBI tentang GCG Bank Syariah betul-betul aktif dan produktif. Pada model pengawasan ini DPS dilakukan oleh sebuah departemen syari'ah di suatu perbankan syari'ah. Dengan model ini ahli syariah bertugas full time, didukung oleh staf teknis yang membentu tugas-tugas pengawasan syariah yang telah digariskan oleh ahi syariah departemen tersebut. Jika model ini diterapkan secara fungsional, maka tugas-tugas DPS sebagaimana yang dihekehendaki DSN dapat terwujud. Kalau DPS melanggar PBI dan sudah diingatkan sebanyhak tiga kali, maka selama 10 tahun, orang tersebut tidak boleh menjadi DPS.

4. Posisi DPS seharusnya sejajar dengan Komisaris. sehingga perannya dan kedudukannya sangat kuat. Ketentuan ini seyogianya masuk dalam Undang-Undang Perbankan Syari'ah. Apabila Dewan Pengawas Syari'ah terlepas dari Bank Indonesia/ Otoritas Jasa Keuangan, maka akibatnya, mereka bekerja dalam pengawasan itu, hanya sambilan saja. Padahal Islam menuntut profesionalisme dan keseriusan dalam setiap pekerjaan, termasuk dalam pengawasan.

5. Kelima, Banyak usulan dari tokoh di daerah, agar bank syari'ah memiliki DPS di daerah. Hal ini sejalan dengan semakin meluasnya kantor cabang perbankan syari'ah ke berbagai wilayah provinsi, bahkan kabupaten /kota. Usulan tersebut positif dan perlu didukung, agar penerapan prinsip syari'ah lebih terjamin di daerah-daerah.

\section{E. Penutup}

Dewan Pengawas Syariah (DPS) sebagai pemegang otoritas pengawasan terhadap kepatuhan syariah (sharia compliance) dalam perbankan syariah di Indonesia, memiliki tanggungjawab dan peranan setral yang diatur melalui ketentuan hukum yang tegas. Dilihat berdasarkan aturan dan undang-undang 
serta praktik yang dilakukan dalam lembaga perbankan syariah, DPS adalah kunci dalam pelaksanaan dan pengawasan sharia compliance). Kedudukan DPS sangat menentukan terciptanya kepatuhan syariah (sharia compliance) yang merupakan unsur utama dalam keberadaan dan kelangsungan usaha bagi industri keuangan syariah.

Beberapa rekomendasi yang dituliskan oleh peneliti utamanya terkait 3 (tiga) fokus utama yang isu dalam optimalisasi peran DPS di Bank Syariah meliputi, standarisasi kompetensi dan kualifikasi seorang DPS, masalah independen yang harus diatur secara jelas dalam regulasi baik oleh OJK maupun pihak Internal bank syariah, serta masalah prosedur pelaksanaan audit syariah yang harus dibakukan secara nasional dalam semua lembaga perbankan syariah. 


\section{DAFTAR PUSTAKA}

Abdullah M. Noman, “Imperatives of Financial Innovations For Islamic Banks”, International Journal of Islamic Financial Services, Vol. 3, (2003), hlm. 1-14

Adrian Sutedi, Perbakan Syariah, Tinjauan dan Beberapa Segi Hukum (Jakarta: Ghalia Indonesia, 2009)

Agus Triyanta, "Implementasi Kepatuhan Syariah dalam Perbankan Islam (Syariah) (studi perbandingan antara Malaysia dan Indonesia)", IIUM (International Islamic University of Malaysia) dalam Jurnal Hukum No. Edisi Khusus Vol.16 Oktober 2009, Unversitas Islam Indonesia, hlm 209228.

Agustianto, “Optimalisasi Peranan Dewan Pengawas Syari'ah", dikutip dari http:/ / www.agustiantocentre.com/, tanggal 2 Mei 2017.

Aziz Budi Setiawan, "Perbankan Syariah; Challenges dan Opportunity Untuk Pengembangan di Indonesia", Jurnal Kordinat, Edisi: Vol.VIII No.1, April 2006, hlm. 1-14.

Bank Indonesia, Peraturan Bank Indonesia Nomor 13/2/PBI/2011 Tentang Pelaksanaan Fungsi Kepatuhan Bank Umum.

Didin Hafidhuddin dan Hendri Tanjung, Manajemen Syariah dalam Praktik, (Jakarta: Gema Insani Press, 2003)

Haniah Ilhami, Pertanggungjawaban Dewan Pengurus Syariah Sebagai Otoritas Pengawas Kepatuhan Syariah Bagi Bank Syariah, Jurnal Mimbar Hukum, Volume 21 Nomor 3, Oktober 2009, hlm. 14-28.

Kautsar Riza Salman, Akuntansi Perbankan Syariah Berbasis PSAK Syariah (Padang: Akademia Permata, 2012)

M. Syafi'i Antonio, Bank Syariah dari Teori ke Praktik, (Jakarta : Penerbit Gema Insani, 2001)

M. Umer Chapra dan Habib Ahmed, Corporate Governance Lembaga Keuangan Syariah, diterj. Oleh Ikhwan Abidin Basri, (Jakarta: Bumi Aksara, 2008) 
Makmur, Efektivitas Kebijakan Kelembagaan Pengawasan, (Bandung; Rfika Aditama, 2011)

Muhammad Ayub, Understanding Islamic Finance, (Jakarta: PT Gramedia Pustaka Utama, 2009)

Rizal Yahya dkk., Akuntansi Perbankan Syariah Teori dan Praktik Kontemporer, (Jakarta: Salemba Empat, 2009)

Shankar Ganesan, "Determinants of Long-term Orientation in Buyer-Seller Relationship", Journal of Marketing, No.58, April, 1994, hlm. 1-19

Sumar'in, Konsep Kelembagan Bank Syariah (Yogyakarta: Graha Ilmu, 2012)

Syayfudin Azwar, Metode Penelitian, cet ke-2 (Yogyakarta: Pustaka Pelajar, 1999).

Todd Saxton, "The Effects of Partner and Relationship Characteristic on Alliance Outcomes", Academy of Management Journal, Vol. 40, No.2, 1997, hlm. 443-461.

Undang-Undang Nomor 21 Tahun 2008 tentang Pebankan Syariah.

Zainal Arifin, Dasar-dasar Manajemen Bank Syariah, (Tangerang: Aztera Publisher, 2009) 